\title{
Submitted Articles
}

Jongkees, L. B. W.: Dedication to Prof. Gerlings.

Arlsan, M. (Padova): Ultrasonic Hypophysectomy in Acromegaly. Report of 41 Cases.

Bottema, T. (Amsterdam): The Esthesioneuroepithelioma.

Calseyde, P. van de; Ampe, W., and Depondt, M. (Bruges): Use of the Torsion

Swing Test in Follow-Up Study of the ENG. Registration in Cases of Unilateral

Labyrinthectomy (will be published in extenso in a following issue of this Journal). Crabbé, F.

(Brussels): Present Trends in the Evaluation of Vestibular Function. Damsié, P. H. (Utrecht):

Vocal Disorders. A Guide to their Diagnosis. Deinse, J. B. van (Den Haag): Some Remarks

about the Covering of the Singing Voice. Grobben, L. M. (Utrecht): Pitch of Short Tones. Groen, J. J. (Utrecht): Puretone Audiometry and Whispered Voice Test, Conformities

and Differences in Test Results (will be published in extenso in a following issue

of this Journal). Ham, H. J. (Utrecht): Modern Radiotherapy in Carcinoma of the Larynx.

Hammelburg, E. (Wassenaar): Noise, Man and Law (will be published in extenso

in a following issue of this Journal). Hoeksema, P. E. (Groningen): Kelly-Paterson Syndrome

and Carcinoma. Huyzing, E. H. (Leiden): The Early Descriptions of the So-Called Tuning Fork

Tests

of Weber and Rinne (will be published in extenso in a following issue of this Journal). Jongkees, L. B. W. and Oosterveld, W. J. (Amsterdam): Sinusoidal Optokinetic

Stimulation. The Use of a Subtractor for the Pendulum-Swing Test. Keynes, R. D. (Cambridge):

Excitable Membranes (has been published in Nature,

Lond. 239: 29-32, 1972). Kupperman, R. (Renkum): The Complexity of Cochlear Adaptation.

Lansberg, M. P. (Zeist): Alternobaric or Pressure Vertigo and the Pseudo-Positive

Fistula Symptom as a Reflex Phenomenon. Reflexogenic Vertigo and Nystagmus. Ledoux, A.

(Liège): Personal Observation of Cochlear Traumas. Leibbrandt, C. C. (Utrecht): Endolymphatic Sac Drainage in Ménière's Disease

(will be published elsewhere in extenso). Leibbrandt, E. H. M. and Leibbrandt, C. C. (Utrecht):

Anesthesia in Laryngectomy. Mater, E. H. and Rieder, W. (Wien): Laryngectomy with

Preservation of the Air

Passages.

Submitted Articles

.133

Marres, E. H. M. A.; Huygen, P. L. M., and de Jong v. d. Brand, O. W. J. M.

(Nijmegen): The Classification of Audiograms in Otosclerosis. Preliminary Report. Mounier-

Kuhn, P. (Lyon): On the Maturation of Human Auditory Function. Pfaltz, C. R. (Basle): The Indication of Infraorbital Nerve Decompression. Portmann, M. (Bordeaux): Surgery of the Internal Auditory Canal (will be published

in extenso in a following issue of this Journal). Rietjens, J. H. (Utrecht): The Pre-Epiglottic Space in Laryngeal Cancer. Sedee, G. A. (Utrecht): Facial Nerve and Dysplasia of the Temporal 
Bone. Struben, W. H. (Rotterdam): Endoscopic Treatment of Esophageal Diverticula. Toivio, I.; Rapo, S.; Siirala, U.; Tallberg, T.; Lauerma, S.; Meurala, H., and Tapannien, J. (Helsinki): Skin andTracheal Homografts Following Splenic Denervation. A Preliminary Report (will be published elsewhere in extenso). Venker, H. (Amersfoort): Sonomanometric Investigation of the Eustachian Tube Function and Tympanoplasty. Venker, J. (Liempde): The Missing Incus. Verbiest, H. (Utrecht): A Short Review of the Collaboration between the Utrecht Departments of Oto-Rhino-Laryngology and of Neurosurgery and a Contribution to Some Macro-Surgical Aspects of Transsphenoidal Hypophysectomy. Wijngaarden, H. A. van and Fokkens, J. K. (Utrecht): The Principle of the 'Aerosol

Sonique' (will be published in extenso in a following issue of this Journal). Wit, G. de (Amsterdam): The Flying Enterprise Symptom. 